\title{
WHY DO SPATIAL DATA AND INFORMATION HAVE A SIGNIFICANT ROLE IN SPATIAL PLANNING PROCESS? THE INVESTIGATION OF SPATIAL DATA AND INFORMATION USAGE IN INDONESIAN SPATIAL PLANNING POLICIES
}

\author{
A. Yudono ${ }^{\mathrm{a}, \mathrm{b}}$ \\ ${ }^{a}$ Department of Urban Studies and Planning, University of Sheffield, United Kingdom \\ ${ }^{b}$ Department of Urban and Regional Planning, Brawijaya University, Indonesia
}

\section{Article Info:}

Received:07 August 2017

in revised form: 10 Dec 2017

Accepted: 28 April 2018

Available Online: 30 April 2018

\section{Keywords:}

Spatial data, information,

development plan, spatial planning

\section{Corresponding Author:}

Adipandang Yudono

University of Sheffield, Sheffield,

United Kingdom

Email: ayudono1@sheffield.ac.uk

\begin{abstract}
In spatial planning processes, the different aspects of human interactions involving political circumstances, social, economics, historical and cultural objectives can be understood through maps or spatial visualisations, because those media can illustrate abstract phenomena into visual images. Spatial data has a role to play in spatial governance by providing thematic spatial information and analysis at all authority scales (Masson-Vincent, 2008). Furthermore, spatial data and information are prerequisites for any participation in planning deliberation helping to create consensus (Campbell \& Masser, 1995). Spatial data and information currently have a role in communicating with all stakeholders (i.e. local authorities, private sectors and communities) whose interests are in development proposals in particular areas in order to decide implementation, priorities in local geographical areas (Dühr, 2007). This paper investigates the role of spatial data and information in Indonesian spatial planning process using archival research method. The empirical studies take a qualitative approach in analysing the results of data collection from fieldwork observation through collecting legal documents and internal institutional reports. Synchronization and consistency between development plan and spatial plan must be ensured in every interrelated spatial policy, so that the various implementation efforts do not lead to conflict. Furthermore, spatial data and information has a crucial role in translating the development strategies into the implementation of the development programme for the implementation of the government's agenda.
\end{abstract}

Copyright (c) 2018 GJGP-UNDIP

This open access article is distributed under

Creative Commons Attribution (CC-BY-NC-SA) 4.0 International license.

How to cite (APA 6th style): Yudono, A. (2018). Why do spatial data and information have a significant role in spatial planning process? : The investigation of spatial data and information usage in Indonesian spatial planning process. Geoplanning: Journal of Geomatics and Planning, 5(1), 131-146. doi: 10.14710/geoplanning.5.1.131-146

\section{INTRODUCTION}

Physical space can be seen being where social systems interact, involving humans with social, economic and environmental aspects (Hall, 2010). These interaction do not always take place in balanced ways that automatically and mutually benefit all parties, because of different capabilities, interests and the cumulative nature of survival in the geospatial world. Hence, space needs to be organised so as to maintain ecological balance and provide support for human and other living organisms in producing and maintaining optimal living conditions (Chadwick, 1971; McLoughlin, 1969; Meadowcroft, 2002).

Spaces for human living as a dynamic circumstance, needs to be planned in ways that not only reflects the quality and coherence of a tier planning programs (National to Sub-National planning levels), but also reflect the quality of spatial planning components. That is, the qualities of the space itself are determined by the realisation of the harmony and balance of the space utilisation in relation to economic, social and environmental carrying capacity factors (Faludi, 2000).

The spatial planning should be based on understanding of the potentials and limitations of the natural environment and the socio-economic development activities in particular areas, as well as the current demands and the preservation of the environment in the future (Hall, 2010). Thus, ideally, available built 
space and environmental conservation need to be set out in an entire spatial planning system at all government levels.

In spatial planning processes, the different aspects of human interactions involving political circumstances, social, economics, historical and cultural objectives can be understood through maps or spatial visualisations, because those media can illustrate abstract phenomena into visual images (Dühr, 2007; Stephenson, 2010). Furthermore, the spatial visualization can assist in mediating planning debates (Healey, 1997), setting planning agendas (Forester, 1982) and incorporating various viewpoints of planning stakeholders (Robbins \& Cullinan, 1996).

Spatial data has a role to play in spatial governance by providing thematic spatial information and analysis at all authority scales (Masson-Vincent, 2008). Furthermore, spatial data and information are prerequisites for any participation in planning deliberation helping to create consensus (Campbell \& Masser, 1995). Spatial data and information currently have a role in communicating with all stakeholders (i.e. local authorities, private sectors and communities) whose interests are in development proposals in particular areas in order to decide implementation, priorities in local geographical areas (Dühr, 2007).

As an essential planning element, spatial visualisation and spatial information can help to achieve spatial planning consensus by shaping attention to relevant spatial issues, communicating strategic planning messages and stimulating planning actions at different government levels or within the private sectors or amongst communities (Dühr, 2007). Spatial visualization has a significant role in integrating different governmental viewpoints for achieving planning goals from national to sub-national levels.

\section{DATA AND METHODS}

This paper investigates the role of spatial data and information in Indonesian spatial planning process using archival research method. The empirical studies take a qualitative approach in analyzing the results of data collection from fieldwork observation through collecting legal documents and internal institutional reports. Archival research of legal documents had the purpose of providing a basic background of the policy context to gain a comprehensive understanding of the role of spatial data in spatial planning policy formulation that has been conducted in the past and likely to be conducted in the future. The primary documents used as the principal references for this study are as follows:

1. Geospatial Information Act No.4/2011

2. Governmental Regulation No.9/2014 of Detailed Geospatial Information Act No.4/2011 implementation

3. Governmental Regulation No.8/2013 of Spatial Planning Map Guides

4. Spatial Planning Act No.26/2007

5. Governmental Regulation No.15/2010 of Spatial Planning Act Practices

6. National Development and Planning System Law No.25/2004

7. Law No.17/2007 of Indonesian Long-term Development Plan 2005-2025

Some of these legal documents have been collected by downloading from the official Indonesian government websites. Other relevant documents that cannot be directly accessed were obtained by writing a formal request letter to the relevant agencies. All documents were downloaded and/or scanned and then stored on a laptop, an external hard disk and cloud storage as a backup.

\section{RESULTS AND DISCUSSION}

\subsection{The Indonesian spatial planning policies}

In general, the comprehensive planning policies in Indonesia is divided into three parts: The Development Plan, the Spatial Plan, and the State Budget Allocation Plan. In practice, the three systems are related and complement urban and regional development and planning.

\section{The development plan}

The Development Plan is a translation of the values contained in the Indonesian Constitution (The Constitution 1945), and ratified in Law No. 25 of 2004 on National Development Planning System (Sistem 
Perencanaan Pembangunan Nasional, SPPN). SPPN is a replacement of the outlines of state policy, Garisgaris Besar Haluan Negara (GBHN) as a result of the Indonesian Constitutional 1945 amendments. SPPN is the implementation of Indonesia's development direction for the long-term development period of 20 years, known as the National Long-Term Plan (RPJPN). This development period is divided into five-year durations known as Medium-Term Development Plans (RPJMN). Finally, the detailed RPJMN is the government's annual implementation plan referred to as the Government Work Plan (RKP) at the province, regency and municipality levels.

\section{The spatial plan}

The spatial plan is a guideline for the optimal harmonious utilization of natural resources, as well as the basis for the country's development priorities in guiding the development of infrastructure and shaping the spatial structure and land use plan. The spatial structure plan relates to the public service networks connected by the infrastructure networks system between different governmental administrative areas (national strategic sites, provinces, regencies and municipalities). The land use plan is concerned with environmental protection and built environment areas. Within this consideration, spatial data and information have a significant role in providing spatial structure and utilization visualization. The Indonesian spatial plan is stipulated in the Law. No. 26 in 2007 and categorized in a hierarchical system at national, province, regency and municipality levels.

\section{The state budget allocation plan}

The implementation of the development plan translated into the spatial plan depends on the state budget allocation that is approved and distributed by the central, province and local government levels. The budget for the operationalization of development and planning is known as the National and sub-national (i.e. province, municipality and regency levels) State Budget. The State Budget Allocation Plan stipulated in Law No.17 / 2003 of State Budget at each government level. The relationship between the Development Plan, the Spatial Plan and the State Budget Allocation Plan can be seen in Figure 1. It shows that the use of spatial data and information is crucial for translating the "language of RPJPN and RPJMN" into the context of development that is tailored to a geographic region. Spatial data and information contained in the spatial plan will identify priorities in determining the amount of the budget to be approved.

From three Indonesian development and planning aspects, very relevant to the focus of this research on spatial data and information usage concerns on the Development Plan and the Spatial Plan. Thus, this section will focus on both plans. The next section discusses in more detail procedures for the operationalization of the Development Plan.

\subsection{The Indonesian development plans}

The Indonesian development plan commenced a new phase in 2005, with the renewed Indonesian developmental vision, marked by fundamental changes in the Indonesian political and governmental system. During 1998-2004 periods, the Indonesian government had commenced the government transition which transformed the Indonesian government system from centralistic to decentralization system. In this period, many laws and regulations were enacted and the Indonesian Constitution 1945 was amended four times. One of the fundamental transformations during the governmental transitions was the enactment of the Indonesian Long-Term Development Plan for 2005-2025.

This plan is the reference for all components of Indonesian society (government, communities, and businesses) in realizing ideals and national objectives in accordance with the vision, mission and agreed goals, so that all efforts of development actors are synergistic and coordinated. The objectives of the Indonesian Long-Term Development Plan of 2005 - 2025 are to achieve an independent, fair, developed nation as a foundation for the next phase of development towards a just and prosperous society in the Republic of Indonesia under Pancasila*) and the Indonesian Constitution 1945. The translation of the vision, mission and goals of Long-Term Development Plan are summarized in the following Table 1. 


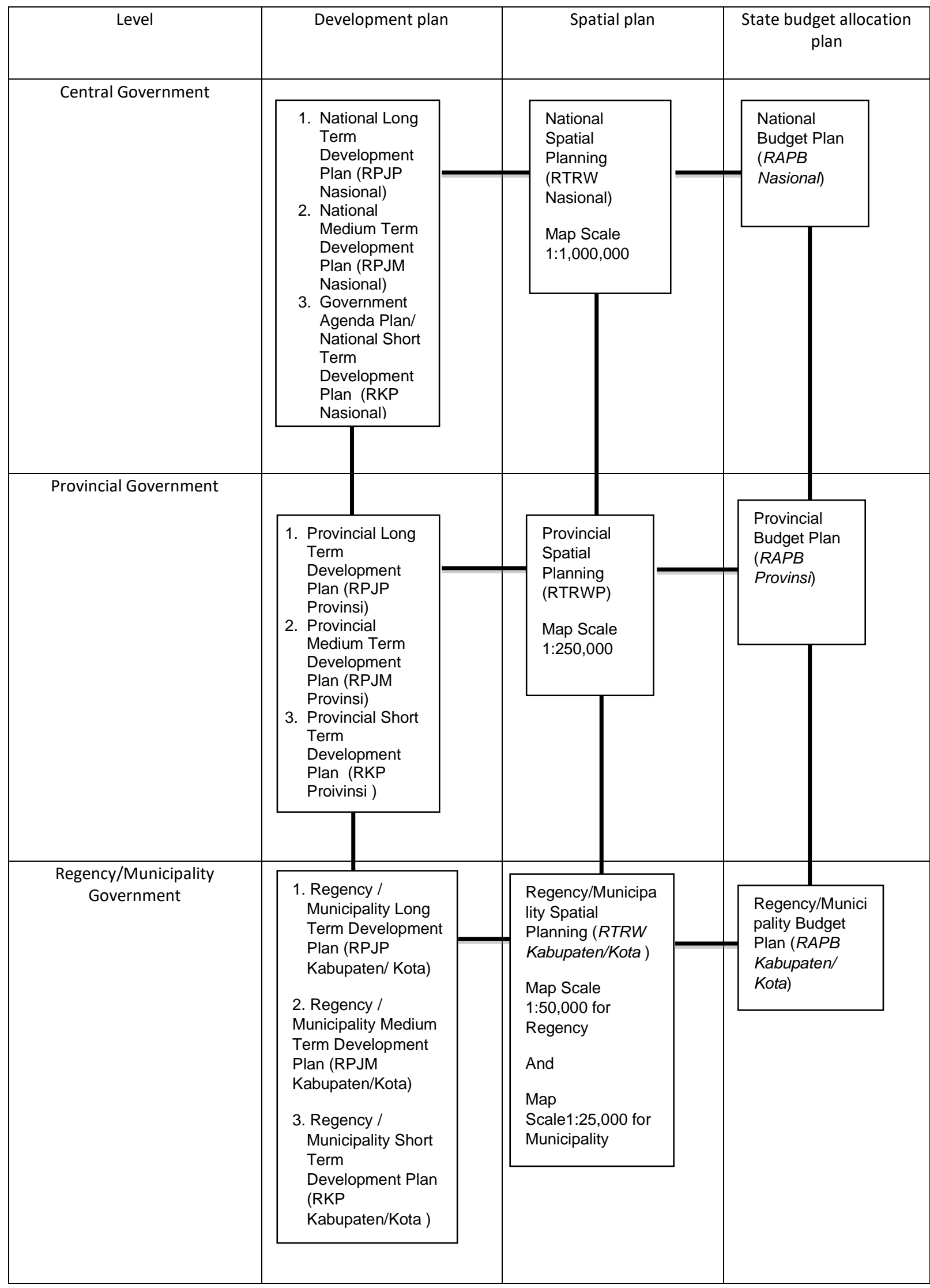

Figure 1. The Relationship Between the Development Plan, The Spatial Plan and The State Budget Allocation Plan (Source: Yudono, 2016) 
Table 1. The Vision, Mission and Goals of The Indonesian Long-Term Development Plan 2005-2025 (Source: The Ministry of Home Affairs, 2017, translated to English by the author in 2016)

Vision $\begin{aligned} & \text { Indonesia as an independent, progressive, fair and prosperous nation } \\ & \text { Mission }\end{aligned}$
1. Realizing a society that has good morality, ethics, culture, and is based on the philosophy of
2. Realizing an energized nation;
3. Creating a democratic society based on law;
4. Realizing a secure, peaceful, and united Indonesia;
5. Achieving equitable development and justice;
6. Realizing a beautiful and sustainable Indonesia;
7. Realizing Indonesia as an independent island state, advanced, powerful, and based on national
interests;
8. Realizing Indonesia plays a significant role in the international community.
1. The realization of Indonesian society that has good morality, ethics, culture, and civilized;
2. Establishing a nation that is competitive to achieve a society that is more prosperous;
3. The realization of a democratic Indonesia, based on law and justice;
4. The realization of security and peace for all people and the integrity preservation in the territory
of the Republic of Indonesia and the sovereignty of the country from all threats, both from
domestic and overseas;
5. The realization of the construction of a more equitable and fairer;
6. The realization of making Indonesia beautiful and sustainable;
7. The realization of Indonesia as an archipelagic nation independent, advanced, powerful, and
based on national interests;
8. The realization of the increased role of Indonesia in the international community.

*) Pancasila is Indonesian state philosophy which has meaning in every Indonesian life aspect, society and the state should be based on the value of the Divinity, Humanity, Unity, Democracy and Social Justice.

Planning and development oversight in the period of $2005-2025$ begins with the implementation of the direct election of the heads of government from central to sub-national levels, and continued with the preparation of the National Development Plan based on Law No. 25 of 2004. In 2010, Law No.17/2010 ratified the basic planning policy and the National Long-Term Development Plan (RJPN) with five-year medium-term development plan (RPJMN) scenarios.

The idea of 20 year period of the National Long-Term Development Plan can be explained that the onset of urbanization in developing countries can lead to a doubling of cities population size over the following 15-20 years (Clarke, 1992). This trend produces increased demands for meeting human needs such as residential, commercial and community services. Since land is a key element of all urban development, spatial plans, which typically intend to control the built environment, designate land uses, capacities for development and urban area utilization, are extremely important to national government.

The RPJPN 2005- 2025 sets policy directions and the priorities to be pursued in the National MediumTerm Development Plan (RPJMN), formulated for five-year periods between 2005-2025. The five-year period, like the 20-year plan, can be derived from Clarke's (1992) studied. He argues that the doubling of population numbers of a particular regions in the next 20 years is likely to lead to long-term social and environment instabilities as well as monetary problems at national, province and local scales. But planning and development programs should focus on short-to-medium term (5-10 year) policies and strategies to monitor urban and regional development.

For Indonesian case, a further reason for the five-year periods of the Medium-Term Development Plan (RPJM) is related to the period of office of the Indonesian President to implement his/her agenda while the short term development period of one year is related to Presidential Cabinet work in realizing the President's vision and mission during one period of office. 


\subsection{How can spatial data and information contribute to the Indonesian development plan process?}

The Indonesian Ministry of National Development and Planning (Badan Perencanaan and Pembangunan Nasional, BAPPENAS) Report as the Ministry that is responsible for preparing Indonesian development plan, commissioned a study from the Indonesia Infrastructure Initiative (INDII) in 2010 on GIS for infrastructure development. The study examines the potential for GIS usage to support BAPPENAS performance, including the preparation of RPJPN, RPJMN and RKP. This section discusses spatial data and information usage in Indonesian development plans in the light of this Report. As discussed in the previous section, the Indonesian development plan is divided into three development plans according to the difference in the time period of development: namely, RPJPN which covers 20 years; RPJMN for periods of five years; and RKP for periods of one year. The study by INDII of spatial data and information potential usage in the national RPJPN can be seen in Figure 2 and for the national RPJM and RKP can be seen in Figure 3.

Figure 2 shows that spatial data and information usage or can benefit from Geographical Information Systems (GIS) in translating the vision and mission of RPJPN 2005 - 2025 is relevant at the stages of prioritizing development programs and for appraisal of development outcomes. Further evaluations of development activities that have the potential for spatial data and information usage are the RPJMN evaluation of prior periods for feedback and improvement in the next RPJM period, as well as the evaluation of public-private partnerships (PKPS) programs. The potential for spatial data and information usage in the spatial development system can be implemented by examining the formulations of regional development priorities and development projects approval set in RPJPN 2005-2025. Spatial analysis of the particular regional characteristics can be identified as socio-economic development issues as the basis for deciding priority development programs in the selected regions.

Once Indonesian Ministry of National Development and Planning has completed formulating the RPJMN, special ministries set up their program proposals. After each ministry finished developing their program proposals, the program proposals are delivered to the particular divisions under BAPPENAS for audit and assessment. The division assesses every system proposition against various criteria: RPJMN program preferences and particular aims, while the Deputy of Funding and the Minister of Finance audit the source and strategies to allocate in the Government Work Plan (RKP). Furthermore, the draft of usage plan and financing for RKP are submitted to the House of Representatives (DPR) for report. In this case, spatial analysis potentially will be used in auditing and assessing program proposals to implement in RPJMN and RKP agenda (See Figure 3).

Overall, spatial data and information usage in development plan documents are not stated explicitly, but examination of the INDII indicates that there is potential for spatial data and information to be used in the audit, assessment and evaluation activities which consider to the development plan goals. In the comprehensive Indonesian development and planning context, development policy language needs to be translated into spatial planning policy language requiring spatial information visualization for the implementation of the government's agenda. Further spatial data and information usage in Indonesian spatial plans will be discussed in the next section.

\subsection{The Indonesian spatial planning system}

The previous section has already mentioned that in terms of the comprehensive Indonesian spatial policy, the manifestation of the development plan is the Spatial Plan, Rencana Tata Ruang Wilayah (RTRW). It becomes the guidelines for all government levels to manage natural resources optimally and sustainability with attention to disaster risk, and as well is the basis for the development of national welfare. In terms of the spatial planning practices in Indonesia (including the regulation, development, implementation, and monitoring), the government has enacted Law No.26 of 2007 . The law regulates the spatial planning system at the national, province and municipality also regency levels (See Figure 4).

The Spatial Plan makes both general and detailed plans of particular areas. A general spatial plan consisting of spatial structure plan and a land use plan, which is formulated based on administrative areas. The spatial structure plan guides the public service networks that are connected by the infrastructure networks system between different governmental administrative areas (national strategic sites, provinces, 
municipalities and regencies); and the land use plan is defined as a land use planning concerned with environment protection and built environment areas.

The detailed spatial plan for a particular area is based on the strategic value of the local approaches and activities with zoning schemes. The preparation of a detailed plan is intended as a spatial plan management tool, and as a basis for setting zoning regulations. The zoning regulations set the terms and conditions for the control of land utilization for each block/zone designated in the detailed spatial master plans.

Spatial structure and land use plan visualization are specified Government Regulation No. 8 of 2013 (PP 8/2013). PP No. 8 / 2013 concerns methods for creating the spatial planning maps in relation to the level of map accuracy, including:

1. Geometric accuracy - geospatial reference system, scale and mapping unit.

2. Details of the spatial planning element maps and symbols.

The relationship between the spatial plan maps and the elements of the spatial planning system - the National Spatial Plan (RTRW Nasional); the Provincial Spatial Plan (RTRW Provinsi); and the Municipality / Regency Spatial Plan, (RTRW Kota or RTRW Kabupaten) - will be discussed in the next section.

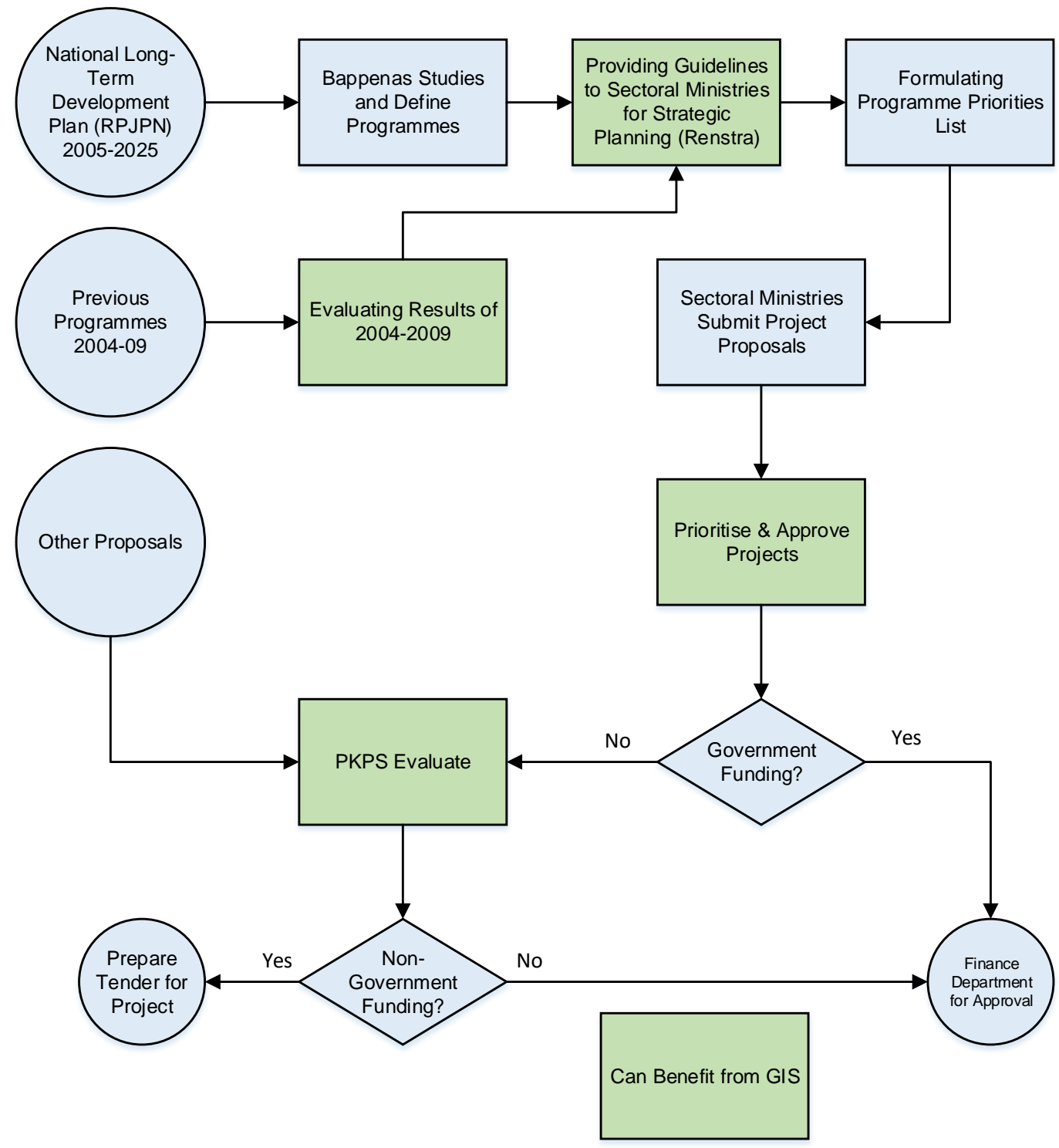

Figure 2. Potential Spatial Data and Information usage fit in the National Long-Term Development Plan (RPJPN) (Source: INDII, 2010) 


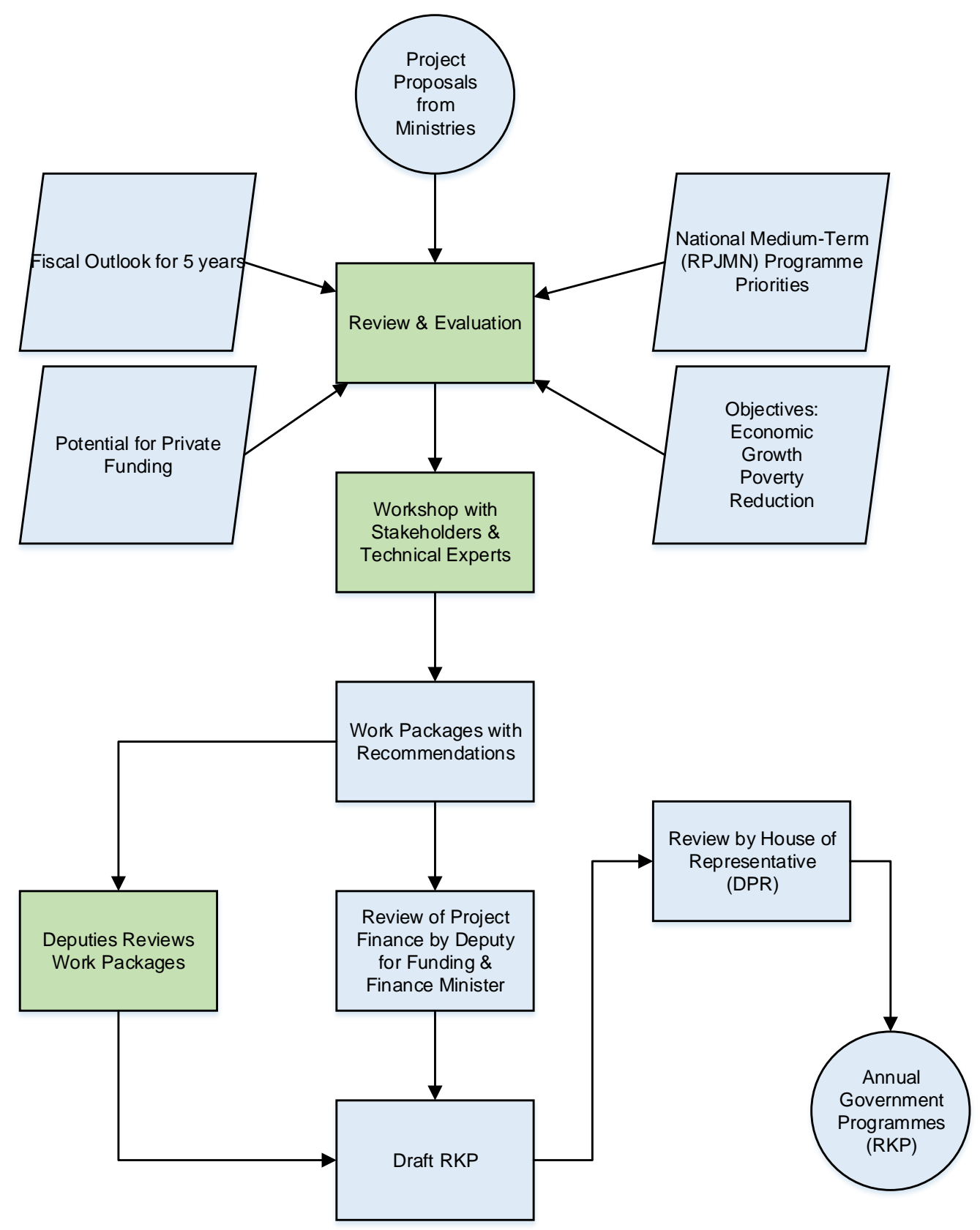

Figure 3. Potential Spatial Data and Information usage fit in the National Medium-Term Development Plan (RPJPMN) and Annual Government Work Plan (RKP) (Source: INDII, 2010)

\section{The national spatial plan}

The Indonesian National Spatial Plan stipulated under Government Regulation No. 26 of 2008 (later will be abbreviated into Gol, 2008) as a reference for government agencies at all levels to determine the location and spatial utilization of the government's agenda and programs. The purpose of national spatial planning reflects the integration of development sectors, regions, and between stakeholders. Policy and national spatial planning strategies are formulated by considering science and technology as ways of making plan, availability of data and information, as well as finance for development.

The National Spatial Plan is formulated for a period of 20 years illustrating the spatial dimension of the Long-Term Development Plan visions. The National Spatial Plan has functions in supervising spatial plans at the provincial and municipality / regency levels to guarantee adherence to laws and consistency amongst systems of planning and advancing congruity of arrangements and activities amongst areas. It also takes the lead in giving providing basic information and data on the conditions of recent spatial development. 
The contents of the National Spatial Plan consist of the Spatial Structure Plan, the Land Use Plan, the establishment of national strategic sites and the national governmental program indicators. In terms of translating the visualization of the National Spatial Plan into the map, there are two elements which are regulated by PP No.8 / 2013: The National Structure Plan and the National Land Use Plan. The fundamental aspects of the National Spatial Plan Maps use 1: 1,000,000 map scale. (See Figure 5). Therefore, a study of spatial data and information usage in the National Spatial Plan needs to focus on both elements.

The National Spatial Structure Plan looks at national urban systems associated with the rural population in a service area and the main infrastructure network systems which have national socio-economic impact. The national urban system consists of urban areas with a covering national and local scale activity centers. The activity center is supported and equipped with a regional infrastructure network, with levels of service tailored to the hierarchy of activities and service needs. The major infrastructure networks are a primary system developed to unify the territory of the Republic of Indonesia and in addition, to serve national scale activities, including transportation, electrical and energy, telecommunications and water resources network systems.

Meanwhile, The National Land Use Plan describes the land use plan, either for national strategic built environment utilization or protected areas. The definition of a National Protected Area is an area in which development is either not permitted or is restricted. It is a space which functions mainly for protecting the health of the environment including natural resources and artificial resources, cultural heritage and history, as well as to reduce the impact of natural disasters. Built Environment Areas have a national strategic value developed to support the functions of national defense and security, regional strategic industry, urban and metropolitan areas, and agricultural regions according to the legislation of licensing and management of a government authority (See Figure 6).

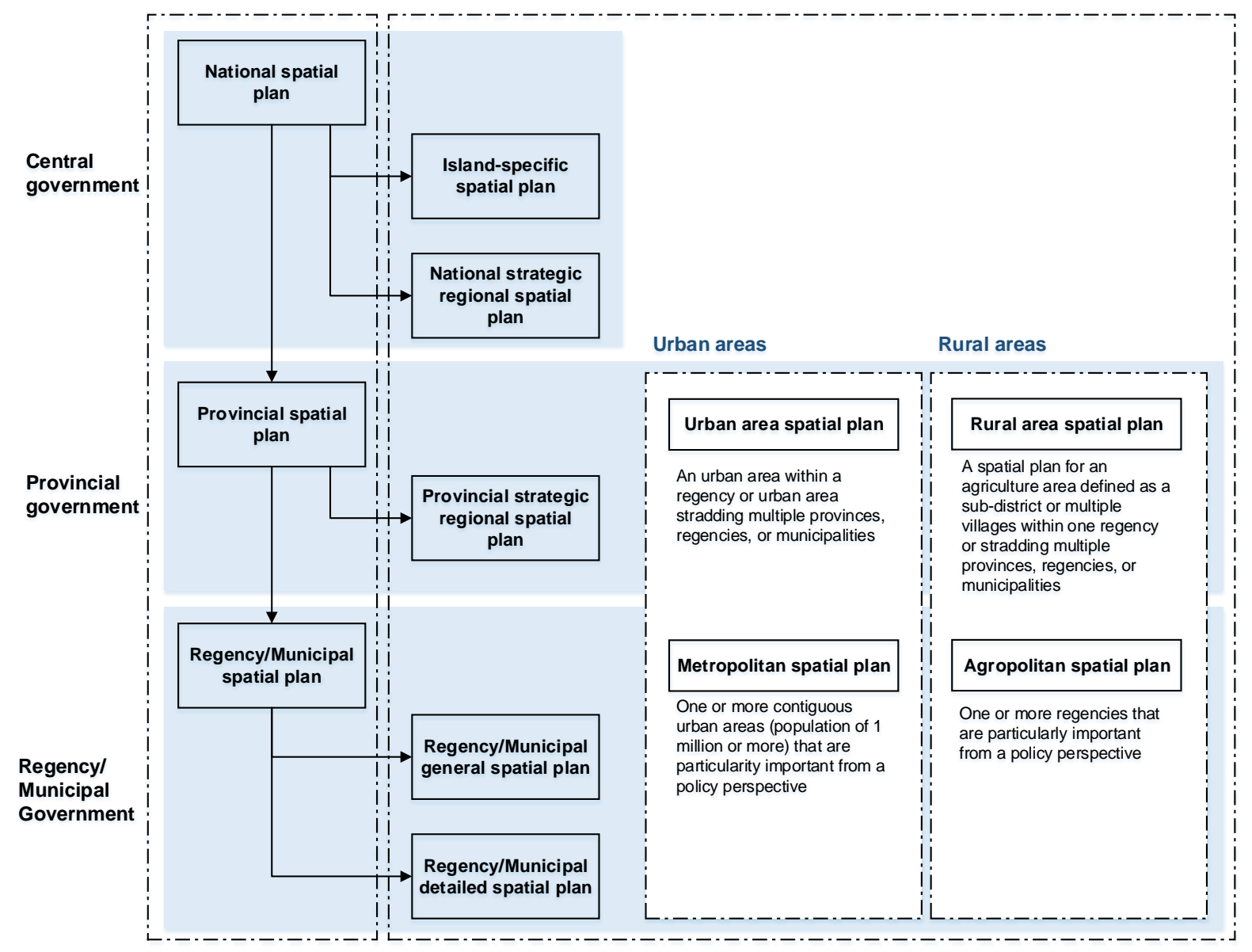

Source: (Ministry of Land, Infrastructure, Transport and Tourism, 2017)

Figure 4. The Hierarchical Spatial Planning System in Indonesia 


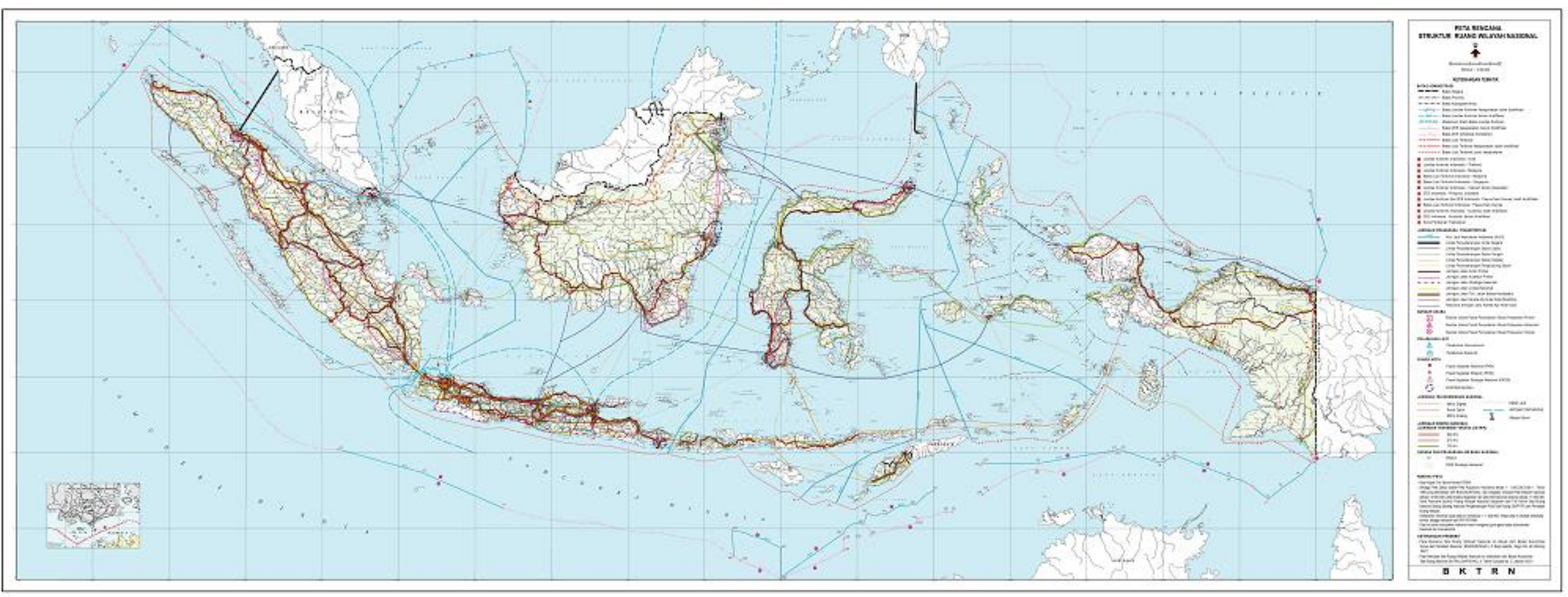

Figure 5. The Indonesian National Structure Plan Map (Source: BIG, 2008, with permission to re-publish from BIG in 2016) 


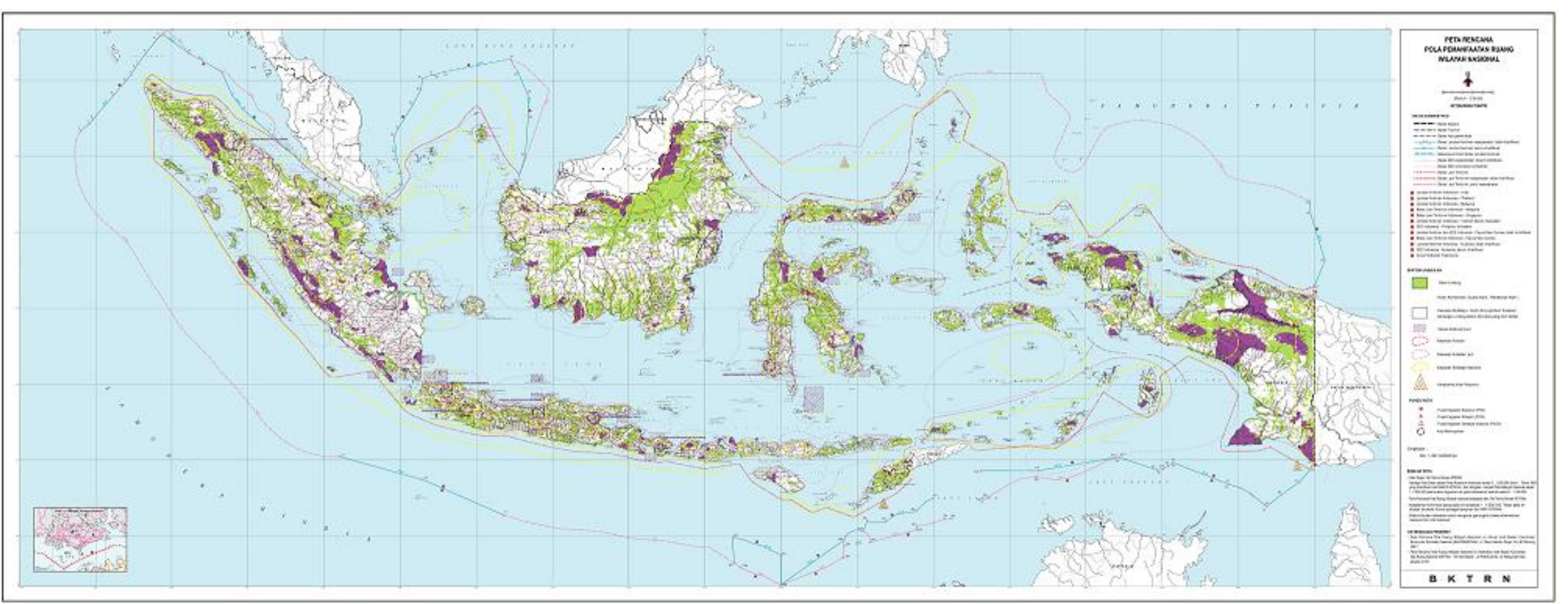

Figure 6. The Indonesian National Land Use Plan Map (Source: BIG, 2008, with permission to re-publish from BIG in 2016) 


\section{The provincial spatial plan}

The Provincial Spatial Plan is the reference for province and local government agencies (i.e. municipality/ regency levels) for determining land use and strategic locations. The Provincial Spatial Plan enshrines integrated alignment and balanced development amongst municipalities / regencies' regions, as well as to synchronize different developmental sectors. The duration of the implementation of Provincial Spatial Plans aligns with the 20 years at the national level. The Provincial Spatial Plan has similar content elements as the national level: The Spatial Structure Plan, Land Use Plan, the establishment of a strategic sites plan, and land use direction and controls. For the purpose of this research, analysis of the contents of spatial plans focuses on the spatial structure and land use plans either at province or regency / municipality levels.

The Provincial Structure Plan is the embodiment of the urban system within the province and the infrastructure network of the province being developed to integrate entire areas at a province level. Spatial structure takes the form of a regional hierarchy starting with the primary activity centers characterized as urban activities, and moving to tertiary activity centers characterized as areas developed predominantly by a particular sector, for example agriculture. The linkages between activity centers in the province are made by the network systems of transportation, energy and electricity, telecommunications, and water resources (including the entire upstream dam / watersheds reservoir areas).

The Provincial Land Use Plan is a picture of the provincial land use system, either having functions for protecting designated areas or built environment utilities. Provincial Protected Areas are ecologically protected areas in which the ecosystem covers more than one regency / municipality and the management is the authority of the provincial government. Built Environment Areas are defined as residential, commercial, mining exploration, industrial estates and tourist resorts areas, having a strategic value for the provincial economy. In terms of translating the visualization of the Provincial Spatial Plan into the map, like the national level, there are two elements regulated by PP No.8 / 2013: The Provincial Structure Plan and the Provincial Land Use Plans. The basic provincial spatial maps are at a scale of 1:250,000.

For provinces with coastal and marine areas, the Spatial Plan Map must be equipped with bathymetry data. For areas bordering other provinces, the Spatial Plan Maps are prepared after the province government coordinates with the adjacent provincial government. Information on the Provincial Spatial Plan Maps shows the borders of two or more provinces with a five-kilometer buffer along the borderlines as a neutral area. Coordination between adjacent provincial governments is a crucial point for spatial plan integration. Relevant to the research topic, spatial data between adjacent provinces is sensitive to potential conflicts, for instance, in land disputes. Thus, open data with specifically spatial data development and sharing is important as a geographical visual communication to achieve spatial plan integration and consensus.

\section{The municipality and regency spatial plans}

The Municipality and Regency Spatial Plan act as the guideline for local governments (municipality and regency, also district (kecamatan) levels) to set the development locations, as well as for local government planning programs. In terms of translating the visualization of the Municipality and Regency Spatial Plan into the map, like the national and provincial levels, there are two elements regulated by PP No.8 / 2013: the Municipality and Regency Structure Plan and the Land Use Plan. The maps are at a scale of 1: 25,000 for municipality and 1:50,000 for regencies.

Furthermore, for municipalities and regencies with coastal and marine areas, the Spatial Plan Maps of the regency and municipality must be equipped with bathymetry data. For regency/municipality areas bordering other regency/municipality areas, Spatial Plan Maps are prepared after the regency/municipality coordinates with the adjacent regency/municipality. Information on the municipality / regency Spatial Plan Maps shows the borders other municipalities / regencies, with a 2,5 kilometers buffer along the border lines as a neutral area.

In the Provincial, Municipal and Regency Spatial Plan ratification process, spatial data and information need to be included as a matter of technical spatial plan maps completeness before spatial plan documents can become regulations and need to have been checked by the Indonesian National Mapping Agency (Badan Informasi Geospasial, BIG) before plans are ratified. BIG supervision procedure of spatial plan maps will be discussed in the next section. 


\subsection{BIG oversight of the formulation of spatial planning policy maps}

When Law No. 26 of 2007 on spatial planning was enacted, all levels of government were required to make spatial plans, including spatial planning maps, for a period of 20 years. The regulation of spatial plan maps is regulated by Article 14 Sections $5 b$ which states that "General spatial plan comprise of planning areas which wide-scale on the spatial plan map needs details of spatial plan policy formulation prior to implementation." Article 14, Section 7 "further provisions on the level of accuracy of the spatial planning map is set by government regulation."

The mechanisms for developing spatial maps are set out in policies from derived Spatial Planning Law, namely Government Regulation (PP) No. 8 of 2013 concerning the accuracy of the spatial plan maps. This PP covers technical preparation of spatial maps ranging from the required thematic maps in spatial plans, reference system, map scale, mapping units and symbols. It also covers associated procedures for the supervision of the preparation of spatial plan maps in order to acquire technical recommendations from BIG under Regulation of the Head of BIG No. 6 of 2014.

The supervision by BIG of spatial plan map production aims to ensure technical accuracy and valid spatial data and information as a reference for spatial plan implementation. The inspection of spatial plan maps covers six aspects based on BIG, 2014 (translated by the author in 2016):

1. Geometric position of base map from BIG;

2. Completion and updated basic spatial data assessment for the base map defined by BIG;

3. Completeness of thematic maps with in accordance with the Ministry of Public Works Regulation No. 20 / PRT / M / 2007;

4. The consistency of spatial plan maps with spatial plan documents that include spatial structure, land use and special areas / strategic plans adjusted with base maps and thematic maps;

5. The consistency of spatial plan maps with provincial/municipal/regency legislation/regulation according to the spatial structure, land use and special areas/strategic plans that meet with the existing regulations;

6. Cartographic presentation with the assessment of symbols, colors, and notation in agreement with Government Regulation No. 8 of 2013.

Generally, the supervision procedure of spatial plan maps provides clear guidelines, but obstacles are encountered is the consultation process carried out directly with the mapping agencies nationwide. The supervision method through direct face-to-face contact between applicants and official BIG staff has been a major obstacle to map development process spatial plans until today, because of it takes high cost and longtime spatial plan process. There is a need for alternative ways of consulting on the production of the spatial maps, for instance, by electronic supervision (e-supervision) method.

\subsection{Synchronizing the Indonesian development plan with spatial plan}

Spatial data or information usage has a crucial role in spatial planning processes to translate the vision, mission and strategy of the Long-Term Development Plan (RPJP) and Medium-Term Development Plan (RPJM) into the Spatial Plan (RTRW). For instance, in RPJP and RPJM, the role of spatial data and information is to describe the general conditions of a region, where the RTRW is translated in the terminology of the region's profile (See Figure 7).

Aspects of the RPJP and RPJM, analysis of strategic issues, policy direction and development strategy is translated into the RTRW with the inclusion of spatial information in the discussion of strategic issues, spatial structure and land use plans. Especially for RPJM, which requires more detailed information for the five-year period of RPJP, an indication of the priority program plans and funding needs to be translated in the land use plan directives enshrined in RTRW (main five-year indication programs). The detailed relationship between Indonesian development and spatial plan can be seen in the following Figure 8.

In summary, synchronization and consistency becomes imperative in every interrelated spatial policy, so that the various implementation efforts do not lead to conflict. In addition, spatial data and information has a crucial role in translating development strategies into the implementation of development programs in the spatial planning context. The Development Plan and Spatial Plan Policy decided by the government has an impact on civil society, especially since the 1992 UN declaration on sustainable development 
emphasized creating a good governance agenda in which implementation should involve communities in urban and regional planning.

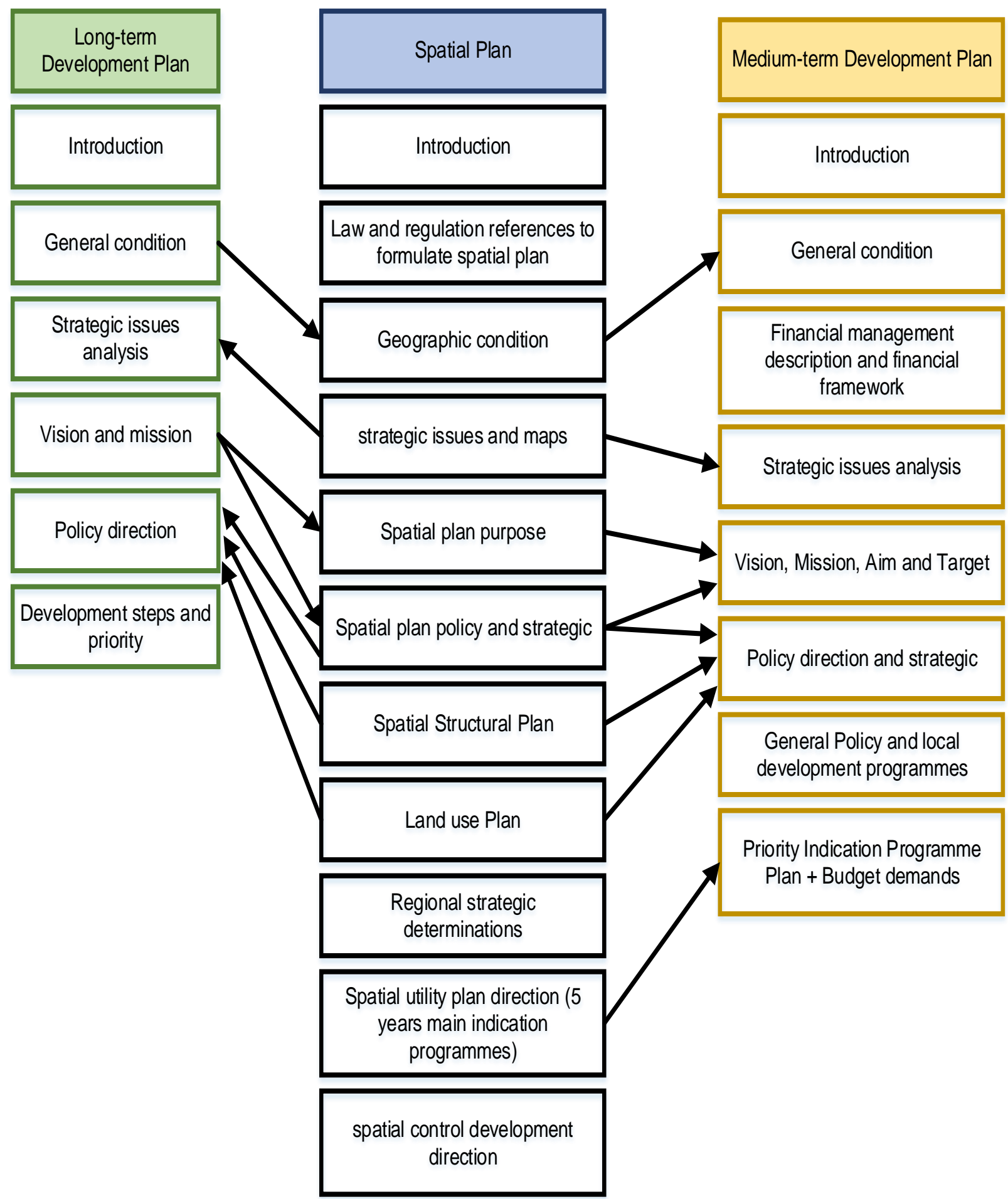

Figure 7. Relations between Long-Term Development Plan - Spatial Plan - Medium Term Development Plan (Source: Rizal, 2008, translated to English by the author in 2016) 


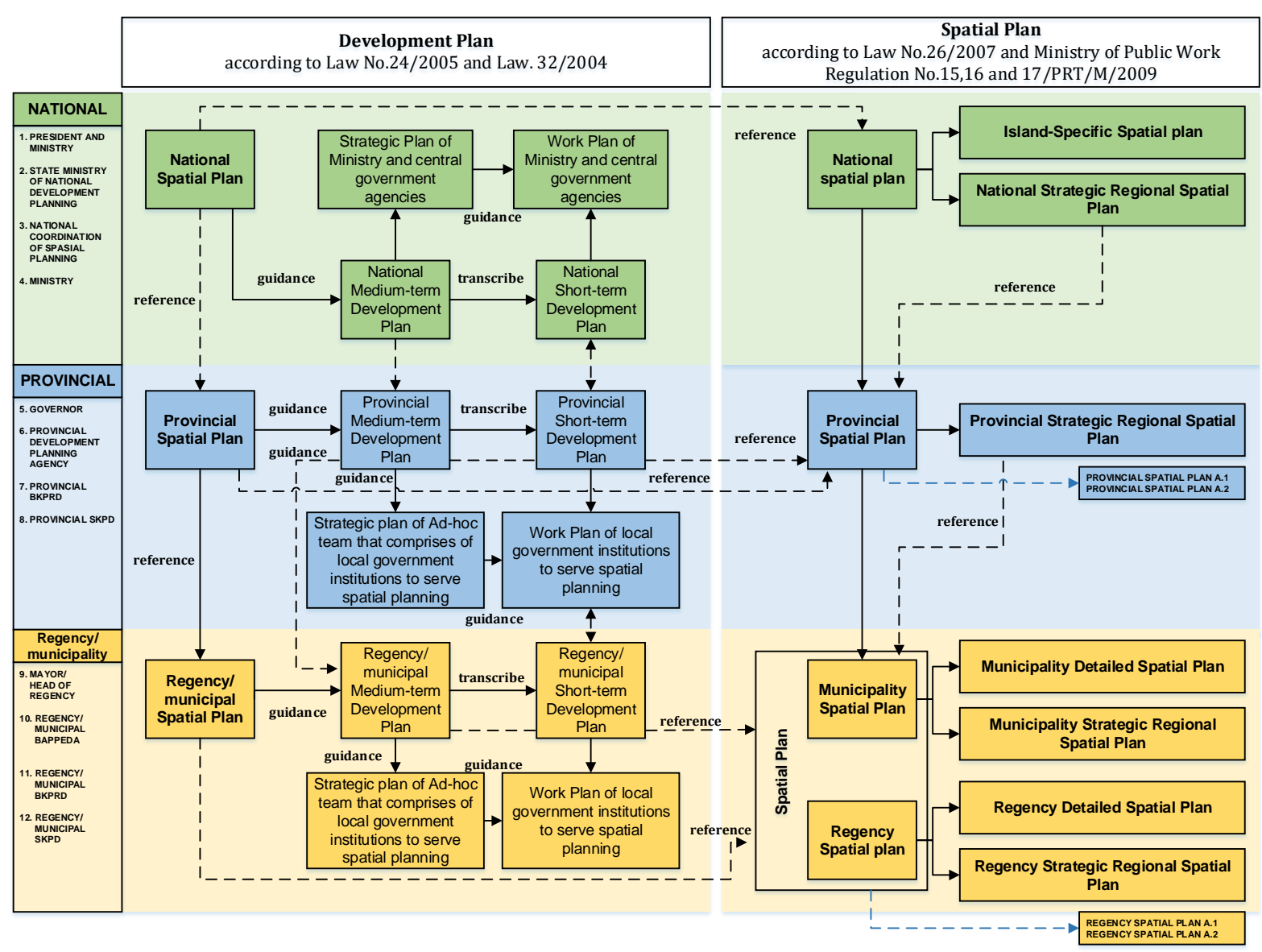

Figure 8. The Detailed Relationship Between the Indonesian Development Plan and The Spatial Plan at All Governmental Levels (Source: Rizal, 2008, translated to English by the author in 2016)

\section{CONCLUSION}

The significant laws relating to the Indonesian planning and development system is Law No. 25/2004 on the National Development Planning System, Sistem Perencanaan Pembangunan Nasional (SPPN), as a replacement of the outlines of state policy, Garis-garis Besar Haluan Negara (GBHN) as a result of the Indonesian Constitutional 1945 amendments. The success of SPPN is supported by the State Budget Allocation Plan stipulated in Law No.17 / 2003 of State Budget at each government level.

The details of SPPN development programs are embodied in the development of the Long-Term Development Plan, Rencana Program Jangka Panjang (RPJP), with the strategy stages undertaken in the five-year Medium Term Development Plan, Rencana Program Jangka Menengah (RPJM) form and the details of every annual stage of strategy in the Government Work Plan, Rencana Kerja Pemerintah (RKP). The work plan for the direction of development of SPPN is a-spatial, and then implemented in spatial form in spatial planning documents, Rencana Tata Ruang Wilayah (RTRW) in accordance with Law. No. 26/2007.

Spatial information visualization in development plan documents are not stated explicitly, but studies by INDII indicate that there is potential for spatial data and information to be used in the audit, assessment and evaluation of development plan goals. The spatial plan is formulated as general and detailed plans of particular areas. A general spatial plan is based on the governmental administrative area with the planning contents essences coming from the spatial structure plan and land use plan.

Government Regulation No. 8 of 2013 (PP 8/2013) sets out the methods for creating spatial planning maps and stipulates the level of map accuracy according to levels of government and purposes of the maps as set out in the Spatial Planning Law. Synchronization and consistency between development plan and spatial plan must be ensured in every interrelated spatial policy, so that the various implementation efforts do not lead to conflict. Furthermore, spatial data and information has a crucial role in translating the development strategies into the implementation of the development program for the implementation of the government's agenda. 


\section{ACKNOWLEDGMENTS}

This paper is part of the author's PhD research. Within this consideration, the author would like to thanks to the Indonesian Endowment Fund for Education (LPDP Scholarship) to support this financial research, also thank you to my supervisor, Dr. Alasdair Rae, with his patient, always support and motivate me to do this research.

\section{REFERENCES (new)}

Badan Informasi Geospasial (BIG), (2014), The Head of BIG Regulation No. 6 of 2014, Tata Cara Konsultasi Penyusunan Peta Rencana Tata Ruang (Procedure for Spatial Plan Formulation supervision).

Campbell, H., \& Masser, I. (1995). GIS In Organizations: How Effective Are GIS In Practice? CRC Press.

Chadwick, G. (1971). A systems view of planning: towards a theory of the urban and regional planing process.

Clarke, G. (1992). Towards appropriate forms of urban spatial planning. Habitat International, 16(2), 149165. [Crossref]

Dühr, S. (2006). The Visual Language of Spatial Planning. Routledge. [Crossref]

Faludi, A. (2000). The Performance of Spatial Planning. Planning Practice and Research, 15(4), 299-318. [Crossref]

Forester, J. (1982). Planning in the Face of Power. Journal of the American Planning Association, 48(1), 6780. [Crossref]

Hall, P. (2010). Urban and Regional Planning. Routledge. [Crossref]

Healey, P. (1997). Collaborative planning: Shaping places in fragmented societies. UBc Press. [Crossref]

Government Regulation. 2008. PP No.26/2008 tentang Rencana Tata Ruang Wilayah Nasional.

(INDII), I. I. I. (2010). GIS for Infrastructure Development Recommendation for Bappenas. The Project Report designed to promote economic growth in Indonesia by enhancing the relevance, quality and quantum of infrastructure investment funed by an Australian Government.

Masson-Vincent, M. (2008). Governance and geography explaining the importance of regional planning to citizens, stakeholders in their living space. Boletin de La Asociación de Geógrafos Españoles, (46), 7795.

McLoughlin, J. B. (1969). Urban \& regional planning: a systems approach. London, UK: Faber and Faber.

Meadowcroft, J. (2002). Planning for sustainable development: what can be learned from the critics? In Planning sustainability (pp. 22-48). Routledge.

The Ministry of Home Affairs. (2017). National Medium Term Development Plan 2005-2031. State Secretariat.

Ministry of Land, Infrastructure, Transport and Tourism, J. (MLIT) (2017). An Overvier of Spatial Policy in Asian and Euroan Countries.

Rizal, K. (2008). Mensinkronkan perencanaan pembangunan dan perencanaan keruangan di Indonesia pola hubungan sistem perencanaan pembangunan nasional (uu no. 25/2004) dengan sistem penataan ruang (uu no. 26/2007) (Synchronizing Development System and Spatial Planning System. Working paper prepared in Ministry of National Planning and Development, Jakarta, Indonesia.

Robbins, E., \& Cullinan, E. (1996). ARCHITECTURE Why Architects Draw, Edward Robbins. 1994. The MIT Press, Cambridge, MA. 300 pages. ISBN: 0-262-18157-6.39.95. Bulletin of Science, Technology \& Society, 16(1-2), 63-64. [Crossref]

Stephenson, J. (2010). People and Place. Planning Theory \& Practice, 11(1), 9-21. [Crossref]

Vincent, M.M, (2008), Governance and Geography Explaining The Importance of Regional Planning to Citizens, Stakeholders in Their Living Space, Boletin de la A.G.E.N, No.46, pp. 77-95.

Yudono, A, (2006), Teknologi, Informasi dan Perencanaan di Indonesia: Quo Vadis One Map Policy? (Technology, Information and Planning in Indonesia: Quo Vadis One Map Policy?), LSC Insight-The Contemporary Policy Issues in Indonesia, Vol.1, No.10. 